\title{
Yield of cheese type Camembert with addition of protein extenders with and without mass stirring
}

\author{
Sérgio Augusto de Sousa Campos ${ }^{1}$; Giovana Maria Pereira Assumpção²; Luiz Ronaldo de Abreu ${ }^{3}$; Sandra \\ Maria Pinto ${ }^{4 *}$
}

\begin{abstract}
Was evaluated the use of dairy protein concentrate $(\mathrm{dpc})$ and the role of mass stirring in the manufacture yield of the cheese type Camembert. Two whey protein concentrate, and two milk protein were used. The stirring or not of the mass in schema split plots in treatments was evaluated. The milk characterization was evaluated in relation to its average values. The cheeses' chemical composition; fat loss and protein in whey; g/L coefficient; yield in L/kg. The $\mathrm{dpc}$ addition, promoted no difference in yeld, did not influence in isolation way in the cheese composition and way in the fat loss in the whey, promoted less loss of protein in whey in treatments with milk protein, in transfer of solids. Stirring or not mass did not change the yield, influenced in isolation way in the fat content of the cheese, presenting them without stirring the higher values, did not influence in isolation way in the fat loss in whey. M1 and M2 treatments showed less loss of protein and fat in whey. It is suggest to manufacture cheeses without stirring, reducing 30 to 40 minutes the manufacture time.
\end{abstract}

Keywords: Dairy protein. Solids transfer. Fat loss. Protein loss.

\section{Rendimento de queijo tipo Camembert com adição de extensores de proteínas com e sem mexedura da massa}

\begin{abstract}
Resumo
Foi avaliado o uso de concentrado proteico lácteo (dairy protein concentrate - dpc) e o papel da agitação em massa no rendimento de fabricação do queijo tipo Camembert. Foram utilizados dois concentrados de proteína de soro e dois de proteínas de leite. A agitação ou não da massa em parcelas subdivididas, em esquema nos tratamentos também foi avaliada. A caracterização do leite foi avaliada em relação aos seus valores médios. A composição química dos queijos; perda de gordura e proteína no soro de leite; coeficiente $\mathrm{g} / \mathrm{L}$; rendimento em L / kg, também foram examinadas. A adição de dpc, não promoveu diferença ao rendimento, não influenciou isoladamente na composição do queijo e na perda de gordura no soro, promoveu menor perda de proteína no soro nos tratamentos com proteína do leite, na transferência de sólidos. A agitação ou não da massa não alterou o rendimento, influenciado de forma isolada no teor de gordura do queijo, apresentando-os sem agitar os valores mais altos, não influenciou de forma isolada na perda de gordura no soro de leite. Os tratamentos M1 e M2 apresentaram menor perda de proteína e gordura no soro de leite. Sugere-se fabricar queijos sem mexer, reduzindo de 30 a 40 minutos o tempo de fabricação.
\end{abstract}

Palavras-chave: Proteína láctea. Transferência de sólidos. Perda de peso. Perda de proteína.

\footnotetext{
${ }^{1}$ Universidade Federal de Lavras. Lavras, MG. Brasil.

https://orcid.org/0000-0001-7518-5343

${ }^{2}$ Instituto Federal de Educação, Ciência e Tecnologia Sudeste de Minas - Campus Barbacena. Barbacena, MG. Brasil.

https://orcid.org/0000-0001-7200-5044

${ }^{3}$ Universidade Federal de Lavras. Lavras, MG. Brasil.

https://orcid.org/0000-0002-8142-415X

${ }^{4}$ Universidade Federal de Lavras. Lavras, MG. Brasil.

https://orcid.org/0000-0001-8431-6034

*Autor para correspondência: sandra@dca.ufla.br
}

Recebido para publicação em 02 de novembro de 2019. Aceito para publicação em 24 de janeiro de 2020.

e-ISSN: 2447-6218 / ISSN: 2447-6218. Atribuição CC BY. 


\section{Introduction}

Cheese production is the most important use of milk produced in many countries and technological parameter percentage of cheese yield (the quantity of cheese obtained from a given quantity of processed milk, expressed as a percentage) is the trace of greater economic importance to the dairy industry (Emmons, 1993).

According to Milkpoint website (2014), the Brazilian cheese market, which is expected to handle approximately $\$ 19$ billion in 2014, has been advancing consistently in recent years and has attracted the attention of foreign companies, which see growth opportunities in the country.

Cheese production is increased while the fat content and milk protein is increased by maintaining or whey reincorporation, and through integration of other milk components such as proteins, lactose or ash, as well as water, called these, extenders (Costa Júnior, 2006).

The protein present in cheese is responsible for retaining almost all of the moisture from the cheese. In terms of yield, this means that any loss of protein also was lost-water that would be retained by this mass (Viotto and Cunha, 2006).

The work carried out with the curds in the tank can influence the cheese yield and should be observed carefully, the cutting speed and the grain size, intensity and time of the mass stirring; factors influencing solids losses, as observed in studies of Everard et al. (2008).

In the specialized literature, there are few studies on the use of whey protein concentrate (wpc) and milk protein concentrate $(\mathrm{mpc})$ in cheeses matured by fungi on the surface, especially the cheese type Camembert. Given the above, this work aims to research the cheese yield type Camembert manufactured with the addition of different dairy protein concentrate (mpc and $\mathrm{wpc}$ ) to the milk for the manufacture and evaluation of mechanical role work with curd (stirring or not of the cheese mass), in the same parameter mentioned above.

\section{Material and methods}

It was collected milks cows freshly milked in the dairy herd at the Federal University of Lavras (UFLA). The present dairy herd selected for the experiment has specialized accompanying certification with veterinarians, in order to ensure the quality of the raw material. The group of cows is composed of 30 (thirty) lactating females, with pedominance of the Dutch breed. The physicochemical quality stands out for the quality in the percentiles of fat and protein, guaranteed mainly by proper nutrition, sanitary management and well-being. Practical hygienics during and after mechanical milking corroborate those resolved.

\section{Dairy protein concentrate}

The dairy protein concentrate (dpc) was provided by the company Tate \& Lyle Gemacom Tech, from Juiz de Fora, MG. Two milk protein concentrate and two whey protein concentrate in two protein concentration were used, as identified: M1 (milk protein concentrate with $47.53 \%$ of protein content), M2 (milk protein concentrate with $54.45 \%$ of protein content), W1 (whey protein concentrate with $49.3 \%$ of protein content) and W2 (whey protein concentrate with $76.69 \%$ of protein content).

Milk samples were analyzed in the laboratory of physical-chemical analysis of the dairy from the Food Science Department of the Federal University of Lavras MG.

\section{Physical-chemical analysis for milk selection for cheese manufacture}

Fat: $(\% \mathrm{~m} / \mathrm{v})$ Gerber butyrometric method; density at $15^{\circ} \mathrm{C}(\mathrm{g} / \mathrm{L})$; protein: Kjeldahl method, total solids: Ackermann calculator disc, titratable acidity: titration method with sodium hydroxide $0,11 \mathrm{~mol} / \mathrm{L}$ (Dornic solution), using the alcoholic phenolphthalein indicator solution, $1 \%(\mathrm{~m} / \mathrm{v})$ neutralized; $\mathrm{pH}$ : it was determined by potentiometric method with potentiometer Tecnal brand (Tec-3MP template) previously calibrated, making up four readings per sample, fixed mineral residue (ash) $\mathrm{m} / \mathrm{m}$ : determined by incineration at $550^{\circ} \mathrm{C}$, lactose percentage content $(\mathrm{m} / \mathrm{v})$ : it was determined by the Chloramine $\mathrm{T}$ method (Brasil, 2006).

\section{Determination of the dpc chemical composition}

Percentage content $(\mathrm{m} / \mathrm{m})$ of moisture and total solids: method in an oven at $85 \pm 2{ }^{\circ} \mathrm{C}$; percentage content $(\mathrm{m} / \mathrm{m})$ of protein: obtained by Kjeldahl method; percentage content of $(\mathrm{m} / \mathrm{m})$ of fat: Roese-Gottlieb method, fixed mineral residue (ash) $\mathrm{m} / \mathrm{m}$ : sample incineration after drying, lactose percentage content $(\mathrm{m} / \mathrm{v})$ : Chloramine T method (Brasil, 2006).

Dairy protein concentrate definition for cheese manufacture type Camembert and extension levels

Pre-laboratory tests were conducted with dairy protein concentrate in different extension levels compared to milk protein content. To define the extension levels for each $\mathrm{dpc}$, it was used past evaluations and results carried out and described in the study of Costa Júnior (2006) with protein extenders in Minas fresh cheese and the following extension levels were tested: 100\%, $80 \%$ $60 \%, 50 \%, 40 \%, 30 \%, 20 \%$ and $10 \%$. The amounts, in grams, of dpc added to the milk for obtaining mixtures with the desired extension levels were calculated by mass balance. 
In this step, the characteristics of curds and whey in each treatment were evaluated. It was established 90 minutes with the maximum time for coagulation according to technology proposed by Furtado and Lourenço Neto (1994). It was used $500 \mathrm{~mL}$ of milk for each treatment.

Mixtures analysis (milk and dpc) and the standardized milk

Content percentage $(\mathrm{m} / \mathrm{m})$ of fat: Gerber butyrometric method; percentage content $(\mathrm{m} / \mathrm{m})$ of protein:
Kjeldahl method, percentage content $(\mathrm{m} / \mathrm{m})$ of fixed mineral residue (ash): determined by incineration at $550{ }^{\circ} \mathrm{C}$; lactose percentage content $(\mathrm{m} / \mathrm{v})$ : Chloramine $\mathrm{T}$ method IN no 68 (Brasil, 2006).

\section{Manufacture of the cheese type Camembert}

The cheeses were manufactured according to Furtado and Neto (1994) with modifications according to Figure 1.

Figure 1 - Flowchart of cheese manufacture type Camembert with and without dpc addition, with and without mass stirring.

Selected, standardized milk (3.2\% fat)

Addition of dairy protein concentrate (dpc)/control

Pasteurization $65^{\circ} \mathrm{C} / 30 \mathrm{~min}$ - Temperature Setting $32^{\circ} \mathrm{C}$ (Removal of 350 $\mathrm{mL}$ sample for analysis)

Addition of mesophilic lactic ferment (pre-maturation of milk at $32{ }^{\circ} \mathrm{C}$ to $0.21 \mathrm{~g}$ lactic acid / $100 \mathrm{~mL}$ of milk)

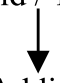

Addition of calcium chloride - Addition of curd $1 \mathrm{~mL} / 10$ liters milk Coagulation 30 to $40 \mathrm{~min}$

Cut into cubes $1.5 \mathrm{~cm}$ edge - Stirring until the point (30 to $40 \mathrm{~min}$ ) - Whey collection 15 minutes after mass cut - Partial syneresis and putting into plastic forms with $250 \mathrm{~g} * *$ Cut into cubes $1.5 \mathrm{~cm}$ edge - Without stirring: rest for 5 minutes - Putting into plastic forms - Whey collection 15 minutes after mass cut

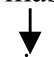

Turns: 15 min after putting into plastic forms, 60 min after the first turning and $60 \mathrm{~min}$ after the second turning

Cheese fermentation in the forms at room temperature $\left( \pm 23^{\circ} \mathrm{C}\right)$ to $\mathrm{pH} 4.7$ 4.8 - and weighing cheese, after 24 hours of manufacture

Salting in brine with $20 \%$ salt at $10{ }^{\circ} \mathrm{C} / 1 \mathrm{~h}$ - Drying $2 \mathrm{~h}\left(10{ }^{\circ} \mathrm{C}\right)$

Spraying of cheese with Penicillium candidum solution prepared 24 hours before use in 5 liters of pasteurized water with $0.5 \mathrm{~g}$ of inoculum Penicillium Storage of cheese unpackaged in BOD $\left(10{ }^{\circ} \mathrm{C} / 93 \%\right.$ of Air Relative Moisture) for 6-7 days until the formation of thin layer of fungus

9-to 10 days full fungus growth $\left(10^{\circ} \mathrm{C} / 93 \%\right.$ of Air Relative Moisture)

12 days package in a layer of plastic film and in other aluminum foil. Storage at $10^{\circ} \mathrm{C}$ in a cold chamber, within 24 days of manufacture

*Manufacture with stirring; ** Manufacture without stirring 


\section{Whey analysis}

Analyses of fat, density, total nitrogen and total solids were carried out following the methodologies described in item physico-chemical analysis for milk selection.

\section{Calculation of Camembert cheese yield}

The manufacture of cheese yield, expressed in liters of milk per $\mathrm{kg}$ of cheese $(\mathrm{L} / \mathrm{kg}$ ) was obtained by dividing the total volume of milk (L) by the total mass of cheese $(\mathrm{kg})$ after 24 hours of manufacture.

The yield was adjusted to the moisture content of 51\% according to Furtado (2003) using the formula described by Furtado (2005).

$$
\mathrm{L} / \mathrm{kgA}=\underline{\mathrm{V}(100-\mathrm{Dm})}
$$

\section{$\mathrm{CP} \times \mathrm{TS}$}

where: $\mathrm{V}=$ volume of milk in liters; $\mathrm{Dm}=\%$ of desired moisture; $\mathrm{CP}$ $=$ cheese production $(\mathrm{kg})$; $\mathrm{TS}=$ total solids

The ciphers of fat loss (1) and protein (2) in whey were calculated according to Furtado (2005) as the formulas below:

$$
\begin{gathered}
\% \text { loss of fat in whey }=(\mathrm{kgl}-\mathrm{Cp}) \times 100 \text { (Eq. 1) } \\
(\mathrm{kgl} / \mathrm{Md}) \mathrm{Mf} \times \mathrm{Wd})) \text { Eq. 2) }
\end{gathered}
$$

where: $\mathrm{kgl}=$ kilograms of milk; $\mathrm{Cp}=$ cheese production in kilograms; $\mathrm{Wf}=\%$ whey fat; Md (density at $15{ }^{\circ} \mathrm{C}$ ) of milk; Mf $=\%$ milk fat; Wd = whey density $\left(15^{\circ} \mathrm{C}\right)$. (2) It was used the same formula (1), replacing the fat content by the whey protein content.

The final recovery of total solids cheese per liter of milk working ( $\mathrm{g} / \mathrm{L}$ coefficient) by formula

$$
\mathrm{g} \mathrm{TS} / 1=\frac{\mathrm{TSxCp}}{\mathrm{V}} 10(\mathrm{Eq} .3)
$$

$\mathrm{TS}=$ total solids $\mathrm{Cp}=$ cheese production in kilograms; $\mathrm{V}=$ volume of milk in liters.

\section{Characterization of cheese type Camembert with a day of manufacture}

Moisture: gravimetric method and calculated by difference (100\% - percentage of total dry extract), total protein: Micro Kjeldahl method, fixed mineral residue (ash): determined by the elimination of organic matter at temperature $550{ }^{\circ} \mathrm{C} ; \mathrm{pH}$ : determined with potentiometer Tecnal brand (Tec-3MP model); total fat: Gerber butyrometric method $(\mathrm{m} / \mathrm{m})$ for cheese, fat in dry matter (FDM) was calculated by dividing the content of fat cheese for their total dry matter content; percentage content $(\mathrm{m} / \mathrm{m})$ lactose: Chloramine-T method (Brasil, 2006).

\section{Experimental design and statistical analysis}

The experimental design was completely randomized (CRD), that compared five treatments TM1, TM2,
TW1, TW2 and CT. Considering the manufacture with and without mass stirring, for cheeses of a production day, it was used the schema split plot in the treatments. The experiments were performed in three replicates the experimental unit consisted of a cheese.

The milk characterization was evaluated in relation to its average values. The chemical composition data of cheeses with and without stirring with one day of manufacture; fat loss and protein in whey; g/L coefficient; cheese yield in $\mathrm{L} / \mathrm{kg}$ were submitted to variance analysis (ANOVA) and when significant applied the Tukey test at 5\% probability. The software used for statistical evaluation was Statistical Analysis System, SAS (2001).

\section{Results and discussion}

According to the results obtained of the milk physico-chemical evaluation aspects used in the fabrication of cheese type Camembert, (data not shown) they met the standards set out in the Normative Instruction $n^{\circ} 62$ December 2011, MAPA (Brasil, 2011).

The dpc protein content are close to those found by Tamine (2009) which ranks as a product with a very high protein content, whey concentrate with values between $72-81 \%$ of protein content, fitting in this reference the dpc of whey W2 (76.69\%) and the dpc W1 (49.3\%) classified as medium protein content. The milk protein concentrate do not have ratings as the protein content, but mpc M1 with $47.53 \%$ and M2 $54.42 \%$ of protein content present similar values to those found by the author cited above. Both milk and whey dairy protein concentrate also have similar compositions to cited by Tamine (2009) in relation to fat, carbohydrate, ash, total dry matter and moisture. Similar compositions for the dpc of whey were found by Yada (2004) and USDEC (2002).

Tables 1 and 2 show the average values of the physico-chemical characteristics of the standardized milk and mixtures used for cheese manufacture with and without stirring, respectively.

Variance analysis showed a significant difference among the compositions of all mixtures (milk standardized $+\mathrm{dpc}$ ). These results may have been influenced in function of the dpc composition used presented significant amounts of these components, contributing to the major differences in mixtures.

Regarding protein content, small differences, smaller or larger, in relation to the intended extension levels were also observed.

Differences were observed among treatments, in the coagulation time in curds characteristics, and whey produced in each manufacture. 
Yield of cheese type Camembert with addition of protein extenders with and without mass stirring

Table 1 - Physico-chemical parameter average content of standardized milk and mixtures (dpc + standardized milk) for cheese manufacture with stirring.

\begin{tabular}{lcccccc}
\hline $\begin{array}{l}\text { Treatment with stir- } \\
\text { ring* }\end{array}$ & $\begin{array}{c}\text { Fat \% } \\
\mathbf{m} / \mathrm{m}\end{array}$ & $\begin{array}{c}\text { Protein } \\
\% \mathrm{~m} / \mathrm{m}\end{array}$ & $\begin{array}{c}\text { Moisture } \\
\% \mathrm{~m} / \mathrm{m}\end{array}$ & $\begin{array}{c}\text { D.M. } \\
\% \mathrm{~m} / \mathrm{m}\end{array}$ & $\begin{array}{c}\text { Ash } \\
\% \mathrm{~m} / \mathrm{m}\end{array}$ & $\begin{array}{c}\text { Lactose } \\
\% \mathrm{~m} / \mathrm{m}\end{array}$ \\
\hline $\begin{array}{l}\text { control } \\
\text { treatment }\end{array}$ & $3.20 \mathrm{c}$ & $4.00 \mathrm{c}$ & $87.30 \mathrm{a}$ & $12.70 \mathrm{c}$ & $0.70 \mathrm{~b}$ & $4.80 \mathrm{c}$ \\
MM1 & & & & & & \\
MW1 & $3.56 \mathrm{~b}$ & $5.21 \mathrm{a}$ & $84.90 \mathrm{c}$ & $15.10 \mathrm{a}$ & $0.87 \mathrm{ab}$ & $5.46 \mathrm{a}$ \\
MW2 & $4.26 \mathrm{a}$ & $5.56 \mathrm{a}$ & $84.23 \mathrm{c}$ & $15.77 \mathrm{a}$ & $0.75 \mathrm{~b}$ & $5.20 \mathrm{~b}$ \\
MM2 & $3.52 \mathrm{~b}$ & $4.50 \mathrm{~b}$ & $86.14 \mathrm{~b}$ & $13.86 \mathrm{~b}$ & $0.76 \mathrm{ab}$ & $5.08 \mathrm{bc}$ \\
CV & $3.24 \mathrm{c}$ & $5.61 \mathrm{a}$ & $84.35 \mathrm{c}$ & $15.65 \mathrm{a}$ & $0.89 \mathrm{a}$ & $5.46 \mathrm{a}$ \\
\hline
\end{tabular}

*MM1: mixture milk standardized + milk protein at $47.53 \%$ of protein content; MW1: mixture milk standardized + whey protein at $49.3 \%$ of protein content, MW2: mixture milk standardized + whey protein at $76.69 \%$ of protein content, MM2: mixture milk standardized + milk protein at $54.42 \%$ protein content. Average followed by the same letter in the column do not differ each other by Tukey test at $5 \%$

Table 2 - Physico-chemical parameter average content of standardized milk and mixtures (dpc + standardized milk) for cheese manufacture without stirring.

\begin{tabular}{lcccccc}
\hline $\begin{array}{l}\text { Treatment without } \\
\text { stirring }\end{array}$ & $\begin{array}{c}* \text { Fat } \\
\% \mathrm{~m} / \mathrm{m}\end{array}$ & $\begin{array}{c}\text { Protein } \\
\% \mathrm{~m} / \mathrm{m}\end{array}$ & $\begin{array}{c}\text { Moisture } \\
\% \mathrm{~m} / \mathrm{m}\end{array}$ & $\begin{array}{c}\text { D.M } \\
\% \mathrm{~m} / \mathrm{m}\end{array}$ & $\begin{array}{c}\text { Ash } \\
\% \mathrm{~m} / \mathrm{m}\end{array}$ & $\begin{array}{c}\text { Lactose } \\
\% \mathrm{~m} / \mathrm{m}\end{array}$ \\
\hline control treatment & $3.20 \mathrm{c}$ & $4.00 \mathrm{~cd}$ & $87.19 \mathrm{a}$ & $12.81 \mathrm{c}$ & $0.71 \mathrm{~b}$ & $4.90 \mathrm{c}$ \\
MM1 & $3,57 \mathrm{~b}$ & $5.22 \mathrm{ab}$ & $84.97 \mathrm{c}$ & $15.02 \mathrm{a}$ & $0.77 \mathrm{~b}$ & $5.46 \mathrm{a}$ \\
MW1 & $4.30 \mathrm{a}$ & $5.41 \mathrm{a}$ & $84.87 \mathrm{c}$ & $15.13 \mathrm{a}$ & $0.91 \mathrm{a}$ & $5.10 \mathrm{~b}$ \\
MW2 & $3.50 \mathrm{~b}$ & $4.35 \mathrm{bc}$ & $86.32 \mathrm{~b}$ & $13.68 \mathrm{~b}$ & $0.75 \mathrm{~b}$ & $5.08 \mathrm{bc}$ \\
MM2 & $3.32 \mathrm{c}$ & $5.50 \mathrm{a}$ & $84.21 \mathrm{c}$ & $15.79 \mathrm{a}$ & $0.91 \mathrm{a}$ & $5.46 \mathrm{a}$ \\
CV & $1.61 \%$ & $6.87 \%$ & $0.43 \%$ & $2.62 \%$ & $7.46 \%$ & $1.74 \%$ \\
\hline
\end{tabular}

*MM1: mixture milk standardized + milk protein at $47.53 \%$ of protein content; MW1: mixture milk standardized + whey protein at $49.3 \%$ of protein content, MW2: mixture milk standardized + whey protein at $76.69 \%$ of protein content, MM2: mixture milk standardized + milk protein at $54.42 \%$ protein content. Average followed by the same letter in the column do not differ each other by Tukey test at $5 \%$.

In treatments which were used the dpc W1 and M2 at 40\% extension, curds and whey were obtained with normal aspects and M1 and W2 treatments with 30\% and $10 \%$ of extension respectively, all with 40 minutes coagulation. CT reached coagulation in 40 minutes. In other extension percentages used there was no coagulation of the milk $(100 \%, 80 \%, 60 \%, 50 \%)$ or fragile curds were obtained without satisfactory characteristics to be worked (40\% for $\mathrm{W} 1$ and $\mathrm{W} 2),(30 \%, \mathrm{~W} 1, \mathrm{~W} 2$ and $\mathrm{M} 2)$, (20\% for all dpc tested), (10\% W1, M1 and M2).

With these results, it was decided to work with the following dpc and extension levels: W2 (dpc whey at76.69\% protein content at 10\% extension); W1 (dpc whey at $49.3 \%$ protein content at $40 \%$ extension); M1 (dpc milk at $47.53 \%$ protein content at at $30 \%$ extension) and M2 (milk protein at $54.42 \%$ protein content at $40 \%$ extension).

In the variance analysis for variable fat, there was a significant interaction between stirring and treatments $(\mathrm{p}<0.05)$, i.e, there is influence of the treatments on stirring and vice versa (Table 3 ).

It was observed that the higher fat content in whey was influenced by does not mass stirring in treatment with dpc of milk used in smaller percentage of TM1 extension.

The fact that does not mass stirring the trend of the consistency is become more fragile with greater possibilities of loss of milk constituents in whey. The stirring contributes to firmness and when performed in appropriate speed and time, may also contribute to the reduction of excessive output of the cheese mass components. Among the manufacture with stirring the fat values showed no statistically significant difference among them $(\mathrm{p}>0.05)$.

In the evaluations of the parameters, protein, variance analysis indicated statistically significant differences among the treatments $(\mathrm{p}<0.05)$ (Table 4). 
de Sousa Campos, S. A. et al.

Table 3 - Whey fat average content of cheese type Camembert manufactured with and without dpc in the treatments' unfolding within the stirring levels.

\begin{tabular}{lccc}
\hline Treatment with stirring* & Average (\%) & $\begin{array}{c}\text { Treatment without } \\
\text { stirring* }\end{array}$ & Average (\%) \\
\hline control treatment & $0.26 \mathrm{a}$ & control treatment & $0.50 \mathrm{~b}$ \\
TW2 & $0.28 \mathrm{a}$ & TM2 & $0.53 \mathrm{~b}$ \\
TM1 & $0.30 \mathrm{a}$ & TW1 & $0.56 \mathrm{~b}$ \\
TW1 & $0.34 \mathrm{a}$ & TW2 & $0.60 \mathrm{ab}$ \\
TM2 & $0.43 \mathrm{a}$ & TM1 & $0.79 \mathrm{a}$ \\
\hline
\end{tabular}

*TM1: standardized milk+dpc milk at 47.53\% protein content; TW1: standardized milk+dpc whey at 49.3\% protein content; TW2: standardized milk + dpc whey at $76.69 \%$ protein content; TM2: standardized milk + dpc milk at $54.42 \%$ protein content. Average followed by the same letter in the column do not differ each other by Tukey test at $5 \%$.

Table 4 - Whey protein average content of cheese type Camembert manufactured with and without dpc addition with and without stirring mass.

\begin{tabular}{lc}
\hline Tratament* & Protein $(\% \mathrm{~m} / \mathrm{m})$ \\
\hline TM1 & $2.95 \mathrm{a}$ \\
TW2 & $2.14 \mathrm{ab}$ \\
TW1 & $2.07 \mathrm{~b}$ \\
TM2 & $2.05 \mathrm{~b}$ \\
control treatment & $1.65 \mathrm{~b}$ \\
\hline
\end{tabular}

*TM1: standardized milk $+\mathrm{dpc}$ milk at 47.53\% protein content; TW1: standardized milk + dpc whey at 49.3\% protein content; TW2: standardized milk + dpc whey at $76.69 \%$ protein content; TM2: standardized milk + dpc milk at $54.42 \%$ protein content. Average followed by the same letter in the column do not differ each other by Tukey test at $5 \%$.

The major content of protein and lactose in whey were presented in TM1, which also showed the highest contents of these components in the mixtures observing the influence of the increase from these components in the increasing content thereof in whey. Protein is an important component of milk related to cheese yield. When is smaller the presence of this component in whey, higher will be the cheese yield.

For the variable ash, there was no statistically significant difference between the manufacturing with and without stirring ( $p>0.05)$ among the treatments ( $p>0.05)$ nor the interaction between stirring*treatments ( $>0.05$ ) showing that the ash content in whey were not affected by the treatments, of the stirring or not the mass, and nor interaction among these factors.

Variance analysis indicated statistically significant difference in the interaction Stirring*Treatment for fat in dry matter of cheese (Table 5).

Table 5 - Percentage average level of fat in dry matter of cheese type Camembert manufactured with and without dpc addition in the treatments' unfolding within the stirring levels.

\begin{tabular}{lclc}
\hline Treatments with stirring & Average (\%) & Treatments without stirring & Average (\%) \\
\hline TW1 & $40.51^{\mathrm{a}}$ & control treatment & $37.39 \mathrm{a}$ \\
TW2 & $37.13 \mathrm{~b}$ & TW1 & $35.73 \mathrm{~b}$ \\
TM1 & $32.28 \mathrm{c}$ & TM1 & $34.11 \mathrm{c}$ \\
control treatment & $32.16 \mathrm{~d}$ & TW2 & $31.48 \mathrm{~d}$ \\
TM2 & $30.61 \mathrm{e}$ & TM2 & $31.45 \mathrm{e}$
\end{tabular}

*TM1: standardized milk + milk protein at $47.53 \%$ protein content; TW1: standardized milk + whey protein at 49.3\% protein content; TW2: standardized milk + whey protein at $76.69 \%$ protein content; TM2: standardized milk + milk protein at $54.42 \%$ protein content. Average followed by the same letter in the column do not differ each other by Tukey test at $5 \%$. 
It was observed that the higher fat content of the mixture TW1 may have influenced the highest content of this component in the cheese, this treatment also showed less fat content in whey. It was observed that in TM2, with lower fat content, was the one with the lowest fat content in the mixture and may have influenced the lower content of this component in cheese.

The treatments' behavior without stirring does not followed the same pattern for the treatments with stirring. In the treatments without stirring mass the largest fat value was obtained by the treatment which was not used dpc, with lower fat content. It does not stirring influenced in the larger mass output from those treatments with higher content of this component, it is inferred.

The Camembert cheese must present fat in dry matter upper to $40 \%$. Only TW1 treatment with stirring mass reached the percentage of fat within the parameter cited by the authors, Spinnler and Gripon (2004).

Variance analysis for the variable protein showed a significant statistical difference $(\mathrm{p}<0.05)$ in the interaction Stirring*Treatment (Table 6).

Table 6 - Average protein content of cheese type Camembert manufactured with and without dpc addition in the treatments' unfolding within the stirring levels.

\begin{tabular}{lclc}
\hline Treatments with stirring & Average (\%) & Treatments without stirring & Average (\%) \\
\hline TM2 & $27.05 \mathrm{a}$ & control treatment & $19.37 \mathrm{a}$ \\
TM1 & $26.69 \mathrm{a}$ & TW1 & $21.08 \mathrm{a}$ \\
control treatment & $20.38 \mathrm{~b}$ & TM2 & $22.50 \mathrm{a}$ \\
TW1 & $19.77 \mathrm{~b}$ & TW2 & $22.75 \mathrm{a}$ \\
TW2 & $19.43 \mathrm{~b}$ & TM1 & $23.67 \mathrm{a}$ \\
\hline
\end{tabular}

*TM1: standardized milk + dpc milk at 47.53\% protein content; TW1: standardized milk + dpc whey at 49.3\% protein content; TW2: standardized milk + dpc whey at $76.69 \%$ protein content; TM2: standardized milk + dpc milk at $54.42 \%$ protein content. Average followed by the same letter in the column do not differ each other by Tukey test at $5 \%$.

It was observed that in the treatments with stirring mass the lowest protein value was recorded in manufactured with added of dpc whey (TW1 and TW2 treatments) can infer that larger amount of soluble proteins may have been lost in whey and loss was enhanced by the mechanical action of stirring and vice versa. Higher proteins values were obtained in the treatments manufactured with the addition of dairy protein concentrate of milk. So, it was observed the influence of the stirring mass on the dpc type used, in the cheese protein content.

It was observed that the treatments with the highest TM2 protein content in manufacture with or without stirring, was the one with the highest protein content in mixture and lower protein in whey.

Lower protein values in relation to the present study were obtained by Dias (2007) (18\%) and Pereira (2014) (15.90\% - summer and 20.14\% winter), in traditional Camembert cheese. Cheeses manufactured in different regions of France have higher protein content between 18.7 to $22.8 \%$, but still lower than those obtained in the present study.

There was a statistically significant difference $(\mathrm{p}<0.05)$ in the interaction Stirring*Treatment, when performed the variance analysis for moisture variable (Table 7).

Table 7 - Average moisture content of cheese type Camembert manufactured with and without dpc addition in the treatments' unfolding within the stirring levels.

\begin{tabular}{lclc}
\hline Treatment WS & Average (\%) & Treatment WOS & Average (\%) \\
\hline TW2 & $59.59 \mathrm{a}$ & TW2 & $52.36^{\mathrm{a}}$ \\
TW1 & $59.25 \mathrm{a}$ & TM1 & $53.12^{\mathrm{a}}$ \\
TM2 & $53.18 \mathrm{~b}$ & TW1 & $53.83^{\mathrm{a}}$ \\
TM1 & $50.43 \mathrm{~b}$ & TM2 & $54.43^{\mathrm{a}}$ \\
control treatment & $49.75 \mathrm{~b}$ & control treatment & $56,79^{\mathrm{a}}$ \\
\hline
\end{tabular}

*TM1: standardized milk + dpc milk at 47.53\% protein content; TW1: standardized milk + dpc whey at 49.3\% protein content; TW2: standardized milk + dpc whey at $76.69 \%$ protein content; TM2: standardized milk + dpc milk at $54.42 \%$ protein content. Average followed by the same letter in the column do not differ each other by Tukey test at $5 \%$. WS $=$ with stirring. WOS $=$ without stirring.

In this work was observed the moisture content under the influence of mechanical action and the type of protein used, since the lower content in the treatments added dpc of milk showed no statistically significant dif- 
ference in relation to the control cheese. It does not mass stirring did not influence the cheese moisture content, regardless of the dpc type used.

According to Furtado (2003) Camembert cheese manufacturing a day should present between 51 and $52 \%$ of moisture to have greater durability in the market. Cheeses evaluated in this study does not fit in this profile, presenting the TM1 treatments with stirring and TW2 without stirring nearby values, being $50.43 \%$ and $52.36 \%$, respectively.

Increased moisture in cheese was observed in a study with Minas fresh cheese manufactured with added protein extenders compared to the control treatment, $63.02 \%$ and $61.43 \%$, respectively in working of Costa Júnior (2006). The same behavior was observed in Cheddar cheeses manufactured with adding whey proteins compared to the control cheese, by Baldwim et al (1985). In the present study this behavior was also observed in the treatments with dpc addition compared to the control cheese.
The functional property of fixing water of the proteins is in part related to its amino acid composition, whereas amino acid residues with charged groups fix more water than the uncharged residues and nonpolar. The higher the number of charged amino acid residues greater its hydration capacity (Dias, 2007). Higher moisture contents obtained in treatments with dpc added of whey may be related to the amino acid composition of these proteins which presents among others, charged amino acids, it is inferred.

Variance analysis showed no statistically significant difference ( $p>0.05$ ) between the manufacture with and without stirring to the ash variable, as well between treatments $(p>0.05)$ and in the interaction Stirring*Treatment ( $>0.05)$, i.e, there is no dependency between stirring and treatments which means that there is no influence of treatments in stirring and vice versa.

The interaction Stirring*Treatment was significant $(\mathrm{p}<0.05)$ for the variable lactose, i.e, there is dependence between stirring and treatments which means that there is influence of the treatments on stirring and vice versa (Table 8).

Table 8 - Average lactose content of cheese type Camembert manufactured with and without dpc addition in the treatments' unfolding within the stirring levels.

\begin{tabular}{lclc}
\hline Treatment with stirring & Average (\%) & Treatment without stirring & Average (\%) \\
\hline TW2 & $3.39 \mathrm{a}$ & TW2 & $4.79 \mathrm{a}$ \\
TM2 & $3.50 \mathrm{a}$ & TW1 & $3.89 \mathrm{~b}$ \\
control treatment & $3.55 \mathrm{a}$ & TM2 & $3.66 \mathrm{bc}$ \\
TW1 & $3.70 \mathrm{a}$ & TM1 & $3.61 \mathrm{bc}$ \\
TM1 & $3.82 \mathrm{a}$ & control treatment & $3.35 \mathrm{c}$ \\
\hline
\end{tabular}

*TM1: standardized milk+dpc milk at 47.53\% protein content; TW1: standardized milk+dpc whey at 49.3\% protein content; TW2: standardized milk + dpc whey at $76.69 \%$ protein content; TM2: standardized milk + dpc milk at $54.42 \%$ protein content. Average followed by the same letter in the column do not differ each other by Tukey test at $5 \%$. WS $=$ with stirring. WOS $=$ without stirring.

It was observed that the lactose content were influenced by the types of dpc and by does not stirring mass in these conditions, the TW2 added of whey dpc, had the highest lactose content. It was also noted that among $\mathrm{dpc}$ the highest average for the lactose were obtained in the treatments added dpc of whey and also in manufacture without stirring, the control treatment showed the lower lactose content. Stirring mass did not influence in the lactose content of the different treatments.

Most of the milk lactose is lost in whey as lactose or lactate during manufacture of the cheese, not having a direct influence on manufacture cheese yield. This disaccharide has an important role in the formation of texture and the final $\mathrm{pH}$ of the cheese mass (Mcsweeney and Fox, 2004).

The variance analysis indicated significant statistical differences $(p<0.05)$ in the interaction between
Stirring*Treatments (Table 9), in relation to fat loss, indicating dependence among the factors.

In the unfolding of interaction treatment with stirring, there was a higher percentage of fat loss in whey in the TM2 treatment. This treatment was also which presented the lowest fat content in cheese and higher fat content in whey. The lower fat loss percentage was observed in the CT treatment that showed no significant difference compared to TW2 and TM1 treatments. It was observed in this result a tendency to decrease the fat recovery when the fat level of the mixture was less and the protein higher (the TM2 treatment was manufactured with the highest protein content and lower fat content and the CT treatment with less fat and protein). A similar result was obtained by Caro et al. (2011) when evaluate Oaxaca cheese yield manufactured using nonfat milk or powdered milk protein concentrate. 
Yield of cheese type Camembert with addition of protein extenders with and without mass stirring

Table 9 - Average values of fat loss in whey of cheese type Camembert manufactured with and without dpc addition in the treatments' unfolding within the stirring levels.

\begin{tabular}{lclc}
\hline Treatment WS & Average (\%) & Treatment WOS & Average (\%) \\
\hline TM2 & $17.02 \mathrm{a}$ & TW1 & $19.28 \mathrm{a}$ \\
TW1 & $10.40 \mathrm{ab}$ & TM1 & $16.54 \mathrm{a}$ \\
TM1 & $8.74 \mathrm{~b}$ & TW2 & $14.66 \mathrm{a}$ \\
TW2 & $8.21 \mathrm{~b}$ & TM1 & $13.99 \mathrm{a}$ \\
control treatment & $6.56 \mathrm{~b}$ & control treatment & $12.29 \mathrm{a}$ \\
\hline
\end{tabular}

*TM1: standardized milk + dpc milk at $47.53 \%$ protein content; TW1: standardized milk + dpc whey at $49.3 \%$ protein content; TW2: standardized milk + dpc whey at $76.69 \%$ protein content; TM2: standardized milk + dpc milk at $54.42 \%$ protein content. Average followed by the same letter in the column do not differ each other by Tukey test at $5 \%$. WS $=$ with stirring. WOS $=$ without stirring.

Fat recovery in the cheese depends on factors related to milk composition and mechanical handling during the process (Callaman, 1991). According to Lucey and Kelly (1994) clot mechanical treatment is one of the factors that most influence in the whey fat recovery.

Among the treatments without stirring no significant differences were observed for the fat loss, while the lowest loss percentage value is in accordance with the highest fat content in cheese and lower fat content in whey for CT.
According to Mietton (1991) the fat cheese recovery of industrial Camembert is from 93 to $95 \%$. Among the results of this study, only the CT treatment with stirring mass reached this average. Variance analysis showed difference $(\mathrm{p}<0.05)$ among the treatments (Table 10).

The most protein loss observed in the TW2 treatment, added dpc of whey may be related to the characteristic of increased solubility of the whey proteins compared to caseins and with that lower protein content may have been retained in the mass.

Table 10 - Average values of protein loss in the whey of cheese type Camembert manufactured with and without $\mathrm{dpc}$ and stirring mass in treatment.

\begin{tabular}{lc}
\hline Treatment & Average (\%) \\
\hline TW2 & $51.37 \mathrm{a}$ \\
TW1 & $38.97 \mathrm{ab}$ \\
TM1 & $33.26 \mathrm{~b}$ \\
control treatment & $33.05 \mathrm{~b}$ \\
TM2 & $28.88 \mathrm{~b}$ \\
\hline
\end{tabular}

*TM1: standardized milk + dpc milk at 47.53\% protein content; TW1: standardized milk + dpc whey at 49.3\% protein content; TW2: standardized milk + dpc whey at $76.69 \%$ protein content; TM2: standardized milk + dpc milk at $54.42 \%$ protein content. Average followed by the same letter in the column do not differ each other by Tukey test at $5 \%$.

This result agrees with those obtained for the highest protein content in whey and lower in cheese for the same treatment TW2.

According to Mietton (1991) the average of protein recovery in industrial manufacture of cheese type Camembert is from $76 \%$ to $77 \%$. Based on these results all treatments have lower use rates of this component, showing the TM2 treatment the best performance among all evaluated with $71.12 \%$ protein recovery rate. The CT showed no significant statistical difference between TM1 and TM2 treatments.

It was not observed influences in the stirring action or not of the mass at in the end use of solid in cheese compared for each liter of working milk $(\mathrm{g} / \mathrm{L}$ Coefficient), as well as the addition of different dpc and the interaction among these factors, because the variance analysis showed no statistically significant difference ( $p>0.05)$ in these assessments.

The average values for the $\mathrm{g} / \mathrm{L}$ coefficient in the treatments with and without stirring mass were $76.88 \%$ and $84.93 \%$, respectively.

In study of Costa Júnior (2006) g/L coefficient values for Frescal cheese with added extensors was $68.98 \%$, against $59.16 \%$ in cheese manufactured without extenders. Compared to the values obtained in this study, treatments with and without stirring mass showed higher $\mathrm{g} / \mathrm{L}$ coefficients. According to Furtado10 the ideal g/L coefficient should be determined for each manufacturing, as is influenced by the milk composition (casein and fat, 
in particular) and of all the factors of manufacture that can alter the final composition of the cheese.

There was no statistically significant difference ( $p>0.05$ ) for the cheese yield in $\mathrm{L} / \mathrm{kg}$ to be carried out or not stirring mass of the cheese. The average for the manufacture with stirring was 6.10 and for manufacture without stirring was 5.55 . The same behavior was observed $(p>0.05)$ among the treatments.

According to Mietton (1991) the manufacture average yield for the traditional Camembert cheese is from 6.66 to $7.14 \mathrm{~L} / \mathrm{kg}$ and 8.0 to $8.5 \mathrm{~L} / \mathrm{kg}$ according to Furtado and Lourenço Neto (1994) The volumes obtained in this study were lower compared to that recommended by the authors.

\section{Conclusion}

Based on the yield of Camembert cheeses made from the addition of different protein concentrates (milk and whey) added to the milk it was concluded that the lower losses of protein and fat in whey and that there is no statistically significant difference in fat loss in whey when does not stirring mass, it can be inferred that using dairy protein concentrate base on milk protein, treatments stand out among the others evaluated. Of the analyzed concentrates, those of milk were the ones that stood out in relation to the others.

Considering that stirring or does not the mass did not influenced in the manufacturing yield, it is suggested that the manufacture are carried out without stirring, which represents a reduction of 30 to 40 minutes in the manufacturing time.

\section{Acknowledgments}

We thank you for the federal university of $L a$ vras, the postgraduate program in food science and the foundation for the support of the Minas Gerais general research (FAPEMIG) for research support.

\section{References}

Brasil. Ministério da Agricultura, Pecuária e Abastecimento. 2006. Instrução Normativa no 68 de 12 de dezembro de 2006. Available in: http://www.in.gov.br/materia/-/asset_publisher/Kujrw0TZC2Mb/ content/id/29896222/do1-2018-07-13-instrucao-normativa-n-30-de26-de-junho-de-2018-29896212.

Brasil. Ministério da Agricultura Pecuária e Abastecimento. 2011. Instrução Normativa no 62, de 29 de dezembro de 2011. Available in:: https://cienciadoleite.com.br/noticia/151/instrucao-normativa-n--62de-29-de-dezembro-de-2011.

Callaman, T. 1991. Recovery of milk constituents in cheesemaking (relation to process control). Internatational Dairy Federation, Brussels.

Caro, I, Soto S, Franco MJ, Meza-Nieto M, Alfaro-Rodríguez RH and Mateo J, 2011. Composition, yield, and functionality of reducedfat Oaxaca cheese: effects of using skim milk or a dry milk protein concentrate. Journal of Dairy Science, 94:580-588. Doi: https://dx.doi. org/10.3168/jds.2010-3102.

Costa Júnior, L. C.G. 2006. Uso de extensores na fabricação de queijo Minas frescal. Lavras: Universidade Federal de Lavras. Thesis .Doctor in Food Science. Available in: http://repositorio.ufla.br/jspui/ bitstream/1/3132/1/TESE_Uso\%20de $\% 20$ extensores $\% 20$ na $\% 20$ fabrica $\%$ C3\%A7\%C3\%A3o $\% 20$ de $\% 20$ queijo $\% 20$ minas $\% 20$ frescal.pdf.

Dias, G. 2007. Influência do uso de Geotrichum Candidum, nas características físico-químicas e sensoriais do queijo tipo camember. Viçosa: Universidade Federal de Viçosa .Dissertation .Master in Food Science and Technology.Available in: https://www.locus.ufv.br/ handle/123456789/2826.

Emmons, D. B. 1993. Economic importance of cheese yield. Factors affecting the yield of cheese. Ed. D.B. Emmons, Brussels.

Everard, C.D.; Callaghan, D. J. O.; Mateo, M.J.; Donnell, C.P.; Castillo, M.; Payne, F.A. 2008. Effects of cutting intensity and stirring speed on syneresis and curd losses during cheese manufacture. Journal of Dairy Science,91:2575-2582. Doi: https://dx.doi.org/10.3168/jds.2007-0628.

Fennema, O.R.; Parkin, K.L.; Damodaran, S. 2010. Química de Alimentos de Fennema. 4 ed. Artmed, Porto Alegre.
Furtado, M. M.; Lourenço Neto, J.P. 1994. Tecnologia de queijos: manual técnico para a .produção industrial de queijos. Dipemar Editora, São Paulo.

Furtado, M. M. 2005. Principais problemas dos queijos: causas e prevenção. Fonte Comunicações, São Paulo.

Furtado, M. M. 2003. Queijos finos maturados por fungos. Ed. Milk Bizz, São Paulo.

Lucey, J.; Kelly, J. 1994. Cheese yield. International Journal Dairy Technology. 47:1-14.Doi: https://doi.org/10.1111/j.1471-0307.1994. tb01264.x.

Mcsweeney, P. L.H.; Fox, P.F. 2004. Metabolism of residual lactose and of lactate and citrate. In: Cheese: Chemistry, Physics and Microbiology. Eds. Fox, P.F.; Mcsweeney, P. L. H.; Cogan, T. M.; Guinee, T. P. Elsevier, London, pp. 361-372.

Mietton, B.1991. Courses on Cheesemaking Technology. National Dairy School of Poigny, Poligny, France.

Milkpoint. 2014. Valor Econômico. Mercado de queijos cresce no país e atrai estrangeiros. Available in: https://www.milkpoint.com.br/ noticias-e-mercado/giro-noticias/mercado-de-queijos-cresce-no-paise-atrai-estrangeiros-91686n.aspx? $r=755629300 \#$.

Pereira, A. C. P. 2014. Características físicas, químicas e microbiológicas de queijos tipo Brie e tipo Camembert produzidos no Brasil. Ponta Grossa: Universidade Estadual de Ponta Grossa Dissertation. Master in Food Science and Technology. Available in: https://tede2.uepg.br/ jspui/handle/prefix/635.

SAS- Statistical Analysis System, User‘s guide: version 9.0. 2001. 40 ed. SAS, institute, INC, North Caroline.

Spinnler, H. E.; Gripon, C. 2004Surface mould-ripened cheeses cheese: chemistry, physics and microbiology. In: Cheese: Chemistry, Physics and Microbiology. Eds. Fox, P.F.; Mcsweeney, P. L. H.; Cogan, T. M.; Guinee, T. P. Elsevier, London, pp. 25-68. 
Yield of cheese type Camembert with addition of protein extenders with and without mass stirring

Tamine, A. Y.2009. Dairy Powders and Concentrated Products. WileyBlackwell, United Kingdom.

USDEC. United States Dairy Export Council. 2002. Características, funções e novas aplicações das proteínas do soro e suas novas frações. Food Ingredients 17:50-56.
Viotto, W.H.; Cunha, C.R. 2006.Teor de sólidos do leite e rendimento industrial. In: Albenones, J. M.; Dürr, J. W.; Coelho, K. O (Ed.). Perspectivas e avanços da qualidade do leite no Brasil. Goiânia: Talento, p. 241-258.

Yada, R.Y. Protein in Food processing. Woodhar Publishing, England. 